\title{
Sodium, potassium and chloride utilization by rats given various inorganic anions
}

\author{
BY SUSAN M. KAUP, ALISON R. BEHLING AND J. L. GREGER* \\ Department of Nutritional Sciences, University of Wisconsin, 1415 Linden Drive, \\ Madison, WI 53706, USA
}

(Received 17 October 1990 - Accepted 5 March 1991)

\begin{abstract}
The purpose of the present studies was to examine the effect of ingestion of sodium and potassium salts of various fixed anions on blood pressure, and to assess interactions among electrolytes. In the first study, Sprague-Dawley rats fed on purified diets supplemented with Na salts of chloride, sulphate, bisulphate, carbonate and bicarbonate for 7 weeks developed higher blood pressures than rats fed on the basal diet. In a second study, rats fed on $\mathrm{Na}$ or $\mathrm{K}$ salts of $\mathrm{HSO}_{4}, \mathrm{HCO}_{3}$ or $\mathrm{Cl}$ had higher blood pressures than rats fed on the basal diet. Blood pressure measurements were not correlated with plasma volume, plasma renin activity, or plasma atrial natriuretic peptide concentrations at 7 weeks. Plasma renin activity was depressed in rats fed on supplemental $\mathrm{Na}$ and even more in rats fed on supplemental $\mathrm{K}$ salts rather than the basal diet. Generally, rats fed on supplemental $\mathrm{Na}$ excreted $\mathrm{Na}$ in urine and absorbed $\mathrm{Na}$ in the gut more efficiently than rats fed on the basal diet or diets supplemented with $K$, but the anions fed also altered $\mathrm{Na}$ absorption and excretion. In a third study, rats fed on diets supplemented with any $\mathrm{Cl}$ salt, but especially $\mathrm{KCl}$, absorbed $\mathrm{K}$ more efficiently than those fed on the basal diet. In studies 1 and 2 , the efficiency of urinary excretion of $\mathrm{K}$ was greatest when $\mathrm{HCO}_{3}$ and $\mathrm{CO}_{3}$ salts were fed and least when $\mathrm{HSO}_{4}$ salts were fed. Despite large variations in the efficiency of absorption and excretion of $\mathrm{Na}$ and $\mathrm{K}$, tissue levels of the electrolytes remained constant.
\end{abstract}

Sodium: Potassium: Chloride: Blood pressure: Rat

Ingestion of not only sodium chloride, but also excess potassium chloride, lysine monohydrochloride and choline chloride, has been found to increase blood pressure and depress plasma renin activity (Kotchen et al. 1983; Whitescarver et al. 1984; Kaup et al. 1991). The aim of the present study was to determine whether other fixed anions, such as sulphate and bisulphate, duplicated the effect of chloride on blood pressure, because Greger et al. (1987), Kaup \& Greger (1990), Kaup et al. (1991), Whiting \& Draper (1981) and Whiting \& Cole (1986) observed that these fixed anions (e.g. $\mathrm{Cl}, \mathrm{SO}_{4}$ and $\mathrm{HSO}_{4}$ ) affected kidney function.

The mechanisms by which ingestion of excess $\mathrm{Cl}$ induces elevated blood pressure are not known. The ingestion of excess $\mathrm{Na}$ is believed to induce changes in blood pressure through one or more of the following mechanisms: expansion of plasma volume, changes in kidney function and changes in plasma renin activity (Tarazi, 1976; Kurtz et al. 1987).

It is also possible that some of the effects of dietary anions could be mediated by changes in excretion and retention of $\mathrm{Na}$ and $\mathrm{K}$. Several investigations have reported that the ingestion of excess $\mathrm{NaCl}$ increased urinary excretion of $\mathrm{K}$ (Castenmiller et al. 1985; Charlton \& Armstrong, 1989). Furthermore, other groups have demonstrated that negative balances with regard to K (Lemann et al. 1965; Ching et al. 1989) and tissue depletion of 
$\mathrm{K}$ (Scandling \& Ornt, 1987) occurred in humans and animals in whom metabolic acidosis was induced by feeding excess ammonium chloride.

Accordingly, in the present studies the effect of variations in dietary anions on blood pressure was assessed and factors monitored that could help explain the mechanisms, i.e. plasma volumes, plasma renin activities, plasma atrial natriuretic polypeptide (ANP) concentrations and excretion and retention patterns of $\mathrm{Na}$ and $\mathrm{K}$.

\section{MATERIALS AND METHODS}

Animals and diets

Two studies were conducted to examine the effect of various inorganic anions. In study 1 , rats (eight per treatment) were fed one of six semi-purified diets for $56 \mathrm{~d}$ : a basal diet or the basal diet supplemented with $\mathrm{Na}(0.4 \mathrm{mmol} / \mathrm{g})$ as $\mathrm{NaCl}, \mathrm{Na}_{2} \mathrm{SO}_{4}, \mathrm{NaHSO}_{4}, \mathrm{Na}_{2} \mathrm{CO}_{3}$ or $\mathrm{NaHCO}_{3}$. In study 2, rats (eight per treatment) were fed on one of seven semi-purified diets for $56 \mathrm{~d}$ : a basal diet, the basal diet supplemented with $\mathrm{Na}(0.4 \mathrm{mmol} / \mathrm{g})$ as $\mathrm{NaCl}, \mathrm{NaHSO}_{4}$, or $\mathrm{NaHCO}_{3}$, or the basal diet supplemented with $\mathrm{K}(0.4 \mathrm{mmol} / \mathrm{g})$ as $\mathrm{KCl}, \mathrm{KHSO}_{4}$ or $\mathrm{KHCO}_{3}$.

In order to assess the effect of variations in electrolyte intake more completely, urinary and faecal samples from a previous study (study A) were also analysed. In study A, rats (eight per treatment) were fed on one of five semi-purified diets for $119 \mathrm{~d}$ : a basal diet or the basal diet supplemented with $\mathrm{Cl}(0.4 \mathrm{mmol} / \mathrm{g})$ as $\mathrm{NaCl}, \mathrm{KCl}$, lysine monohydrochloride and lysine monohydrochloride with $0.2 \mathrm{mmol}$ calcium/g as calcium carbonate.

Weanling, male Sprague-Dawley rats (Harlan Sprague-Dawley, Madison, WI) were housed individually in stainless-steel, wire-bottomed cages. The facilities met the requirements of the Institutional Animal Care and Use Committee.

The diets contained $(\mathrm{g} / \mathrm{kg}): 200$ lactalbumin (Teklad Test Diets, Madison, WI), 50 cellulose (Teklad Test Diets), 50 maize oil, 10 AIN-76 vitamin mixture (Teklad Test Diets), 2.3 choline dihydrogen citrate, 500 sucrose, 50-150 maize starch and 35 AIN-76 mineral mix (American Institute of Nutrition, 1977). The salts were added to the respective diets with maize starch being varied to balance the diets. The analysed electrolyte contents of diets are listed in Table 1.

Deionized water was offered ad lib. Feed consumption was recorded daily. Rats were weighed once weekly.

\section{Sample collection and analyses}

Systolic blood pressure measurements were made during weeks 7-8 in both studies 1 and 2 by an indirect rat-tail cuff blood-pressure system (Harvard Apparatus, South Natick, MA). Rats were placed in a restrainer and the blood pressure was monitored. It was determined that the systolic blood pressure readings stabilized after rats had been placed in the restrainer two or three times. Then, blood pressure was measured at least twice on each rat on at least two different days. Thus, the averages of at least four measurements in stabilized rats are reported.

Urine was collected on days 53-54 and 117-118, days 50-51, and days 52-53 of studies A, 1 and 2 respectively. Urine was acidified, diluted and frozen. Faeces were collected on days 53-59 and 113-117 of study A. Faeces were dried to a constant weight, cleaned of foreign adhering matter and ground to a fine powder.

Rats were fasted overnight, anaesthetized and killed by exsanguination at the conclusion of each study. Plasma volume was determined in study 1 using an Evans blue dye binding method as modified and described previously (Kaup et al. 1991) In study 2, blood was collected via cardiac puncture in EDTA-treated tubes with aprotinin (500 trypsin inhibitor 
Table 1. Chloride, sodium and potassium content $(\mathrm{mg} / \mathrm{g})$ of diets*

\begin{tabular}{|c|c|c|c|}
\hline Diets & Chloride & Sodium & Potassium \\
\hline \multicolumn{4}{|l|}{ Study A } \\
\hline Basal & 1.8 & $1 \cdot 4$ & $3 \cdot 4$ \\
\hline \multicolumn{4}{|l|}{ Basal supplemented with: } \\
\hline Sodjum chloride & $15 \cdot 5$ & $11 \cdot 2$ & $3 \cdot 4$ \\
\hline Potassium chloride & $15 \cdot 3$ & $1 \cdot 3$ & $19 \cdot 1$ \\
\hline Lysine monohydrochloride & $15 \cdot 6$ & 1.2 & 3.4 \\
\hline $\begin{array}{l}\text { Lysine monohydrochloride } \\
+ \text { calcium }\end{array}$ & $15 \cdot 4$ & $1 \cdot 1$ & $3 \cdot 4$ \\
\hline \multicolumn{4}{|l|}{ Study 1} \\
\hline Basal & $2 \cdot 1$ & $1 \cdot 4$ & $3 \cdot 2$ \\
\hline \multicolumn{4}{|l|}{ Basal supplemented with: } \\
\hline Sodium chloride & $17 \cdot 4$ & $10 \cdot 4$ & $3 \cdot 4$ \\
\hline Sodium sulphate & 1.9 & $10 \cdot 1$ & $3 \cdot 4$ \\
\hline Sodium bisulphate & $2 \cdot 0$ & $10 \cdot 3$ & 3.6 \\
\hline Sodium carbonate & $2 \cdot 0$ & $9 \cdot 8$ & $2 \cdot 8$ \\
\hline Sodium bicarbonate & $2 \cdot 0$ & $10 \cdot 0$ & $3 \cdot 0$ \\
\hline \multicolumn{4}{|l|}{ Study 2} \\
\hline Basal & 1.7 & $1 \cdot 4$ & $3 \cdot 4$ \\
\hline \multicolumn{4}{|l|}{ Basal supplemented with: } \\
\hline Sodium chloride & $15 \cdot 8$ & $11 \cdot 6$ & $3 \cdot 6$ \\
\hline Potassium chloride & 148 & 1.5 & $20 \cdot 4$ \\
\hline Sodium bisulphate & 1.5 & $11 \cdot 6$ & 3.6 \\
\hline Potassium bisulphate & $1 \cdot 6$ & $1 \cdot 0$ & $18 \cdot 0$ \\
\hline Sodium bicarbonate & $1 \cdot 5$ & $11 \cdot 1$ & $3 \cdot 0$ \\
\hline Potassium bicarbonate & $1 \cdot 7$ & 1.6 & $17 \cdot 0$ \\
\hline
\end{tabular}

* For details of dietary treatments, see p. 524.

units (Sigma Chemical Co., St. Louis, MO)/tube), trypsin inhibitor (1000 sodium-benzoylL-arginine ethyl ester (BAEE) units/tube) and phenylmethanesulphonyl fluoride $\left(1 \times 10^{-5} \mathrm{M}\right)$. Plasma was stored at $-60^{\circ}$ and subsequently used for determination of plasma renin activity and ANP. Kidneys and tibias were excised, cleaned and weighed. All tissue samples were placed in acid-washed containers and frozen until analyses were done. Plasma levels of ANP (pmol/l) were measured using a commercial radioimmunoassay (Peninsula Laboratories, Belmont, CA). Plasma renin activity was measured by using a commercial radioimmunoassay for angiotensin I (Du Pont Company, Billerica, MA). Plasma renin activity was expressed as $\mathrm{ng}$ generated angiotensin $\mathrm{I} / \mathrm{ml}$ per $\mathrm{h}$.

Diets, urine, faeces and tissues were analysed for $\mathrm{Na}$ and $\mathrm{K}$ by atomic absorption spectroscopy (Greger \& Snedeker, 1980). Diets, urine and faeces were analysed for Cl by a colorimetric procedure (Jeffery \& Hutchinson, 1981). Milk standard (SRM 1549) and urine standard (SRM 2670) obtained from the National Institute of Standards and Technology (NIST) (Gaithersburg, MD) were analysed with experimental samples. Milk standards were determined to contain (\%) $111(n 52), 96(n 36)$ and $102(n 37)$ of the certified NIST value for $\mathrm{Na}, \mathrm{K}$ and $\mathrm{Cl}$. Urine standards were determined to contain (\%) 91 (n 31), 94 ( $n 33)$ and $109(n 9)$ of the certified NIST value for $\mathrm{Na}, \mathrm{K}$ and $\mathrm{Cl}$.

Percentage urinary excretion of minerals was calculated by the formula: (urinary loss/intake) $\times 100$. Percentage apparent absorption of minerals was calculated by the formula : ((intake - faecal loss $) /$ intake $) \times 100$. 
Table 2. Study 1 $\$$. Systolic blood pressures and plasma volumes of rats fed on sodium salts of various inorganic anions§

(Values are means of eight observations)

\begin{tabular}{|c|c|c|}
\hline Dietary treatments & $\begin{array}{l}\text { Systolic blood pressure } \| \\
\qquad(\mathrm{mmHg})\end{array}$ & $\begin{array}{l}\text { Plasma volume } \| \\
(\mathrm{ml} / \mathrm{kg} \text { body-wt) }\end{array}$ \\
\hline $\begin{array}{l}\text { Basal } \\
\text { Basal supplemented with. }\end{array}$ & $149^{* *}$ & $2 \cdot 96$ \\
\hline Sodium chloride & 160 & $2 \cdot 90$ \\
\hline Sodium sulphate & $169 \dagger$ & $2 \cdot 78^{+}$ \\
\hline Sodium bisulphate & 159 & 3.08 \\
\hline Sodium carbonate & 162 & $2 \cdot 89$ \\
\hline Sodium bicarbonate & 156 & $2 \cdot 84$ \\
\hline Pooled SEM & 3 & 0.09 \\
\hline
\end{tabular}

Value for basal diet was significantly different from those for all other treatments: ${ }^{* *} P<0 \cdot 01$.

Values for basal diet supplemented with $\mathrm{Na}_{2} \mathrm{SO}_{4}$ were significantly different from those for basal diet supplemented with sodium bisulphate: $\dagger P<0.05$.

$\ddagger$ For details of procedures, see p. 524 .

$\S$ For details of dietary treatments, see p. 524.

If Significant comparisons by orthogonal contrasts.

\section{Statistical analysis}

The effects of dietary treatments were evaluated within the framework of general linear models for analysis of variance (SAS Institute Inc., 1985). In studies 1 and 2, balanced orthogonal contrasts were devised and used to differentiate among means for variables that had been significantly $(P<0.05)$ affected by the treatments. In study $\mathrm{A}$, tests for least significant differences were used to differentiate among means.

RESULTS

In both studies 1 and 2, rats fed the supplemental salts ( $\mathrm{Na}$ or $\mathrm{K}$ ) for 7 weeks had elevated blood pressures (Tables 2 and 3). In study 1, rats fed on supplemental $\mathrm{HSO}_{4}$ had lower blood pressures than rats fed on supplemental $\mathrm{SO}_{4}$.

The mechanisms are not clear. In study 1 , the dietary treatments did not generally have a sustained effect on plasma volume. However, rats fed on $\mathrm{NaHSO}_{4}$ had proportionally larger plasma volumes than rats fed on $\mathrm{Na}_{2} \mathrm{SO}_{4}$. Increases in blood pressures were not correlated with plasma volume measurements.

In study 2 , rats fed on $\mathrm{Na}$ or $\mathrm{K}$ salts had significantly lower plasma renin activity than rats fed on the basal diet, and rats fed on supplemental $\mathrm{K}$ had lower renin activity than rats fed on supplemental $\mathrm{Na}$. Ingestion of supplemental $\mathrm{HSO}_{4}$ rather than $\mathrm{HCO}_{3}$ also significantly affected plasma renin activity.

Plasma ANP did not appear to be affected differently by the ingestion of $\mathrm{Na}$ or $\mathrm{K}$ salts, but plasma ANP activity was greater when rats consumed $\mathrm{HSO}_{4}$ rather than $\mathrm{HCO}_{3}$. Neither plasma renin activity nor ANP concentrations were correlated to blood pressure measurements.

The differences in blood pressure of rats were not related to the weights of the rats. At the end of $56 \mathrm{~d}$ in study 1, rats fed on the basal diet, or diets supplemented with $\mathrm{NaCl}$, $\mathrm{Na}_{2} \mathrm{SO}_{4}, \mathrm{NaHSO}_{4}, \mathrm{Na}_{2} \mathrm{CO}_{3}$ or $\mathrm{NaHCO}_{3}$ weighed 325, 310, 306, 246, 304 and $309 \mathrm{~g}$ respectively. Those rats fed on $\mathrm{NaHSO}_{4}$ weighed significantly less than the other rats. At the end of $58 \mathrm{~d}$ in study 2 , rats fed on the basal diet or diets supplemented with $\mathrm{NaCl}, \mathrm{KCl}$, 
Table 3. Study 2§. Systolic blood pressures, plasma renin activities and plasma atrial natriuretic polypeptide (ANP) concentrations of rats fed on sodium or potassium salts of various inorganic anions $\|$

(Values are means of eight observations)

\begin{tabular}{|c|c|c|c|}
\hline Dietary treatments & $\begin{array}{l}\text { Systolic blood pressure } \\
(\mathrm{mmHg})\end{array}$ & $\begin{array}{c}\text { Plasma renin activity } \\
\text { (ng generated angiotensin } \mathrm{I} / \mathrm{ml} \text { per } \mathrm{h} \text { ) }\end{array}$ & $\begin{array}{l}\text { Plasma ANPq } \\
(\mathrm{pmol} / \mathrm{l})\end{array}$ \\
\hline Basal & $148^{* *}$ & $9 \cdot 78^{* *}$ & $249 * *$ \\
\hline \multicolumn{4}{|l|}{ Basal supplemented with: } \\
\hline Sodium chloride & 156 & $7 \cdot 59+\dagger$ & 210 \\
\hline Potassium chloride & 157 & $5 \cdot 42$ & 306 \\
\hline Sodium bisulphate & 163 & $9 \cdot 48+\uparrow$ & 310 \\
\hline Potassium bisulphate & 157 & 5.73 & 260 \\
\hline Sodium bicarbonate & 157 & $8.09+\dagger$ & $216 \ddagger$ \\
\hline Potassium bicarbonate & 162 & 5.64 & $192 \ddagger$ \\
\hline Pooled SEM & 3 & 0.69 & 23 \\
\hline
\end{tabular}

Values for basal diet were significantly different from those for all other treatments: $* * P<0-01$.

Values for basal diets supplemented with $\mathrm{Na}$ were significantly different from those for basal diets supplemented with $\mathrm{K}: \dagger \dagger P<0 \cdot 01$.

Values for $\mathrm{HCO}_{3}$ treatments were significantly different from those for $\mathrm{HSO}_{4}$ treatments: $\ddagger P<0 \cdot 0$.

$\S$ For details of procedures, see pp. 524-525.

|| For details of dietary treatments, see p. 524.

I Significant comparisons by orthogonal contrasts.

Table 4. Study $A^{*}$. Urinary excretion (\%) of chloride, sodium and potassium by rats fed on various chloride salts $\dagger$

(Values are means of eight observations)

\begin{tabular}{|c|c|c|c|c|c|c|}
\hline \multirow[b]{2}{*}{ Dietary treatments } & \multicolumn{2}{|c|}{ Cl } & \multicolumn{2}{|c|}{$\mathrm{Na}$} & \multicolumn{2}{|c|}{$\mathrm{K}$} \\
\hline & Week 7 & Week 16 & Week 7 & Week 16 & Week 7 & Week 16 \\
\hline Basal & $47^{\mathrm{b}}$ & $66^{\mathrm{c}}$ & $37^{\mathrm{c}}$ & $59^{\mathrm{bc}}$ & $54^{\mathrm{c}}$ & 65 \\
\hline \multicolumn{7}{|l|}{ Basal supplemented with: } \\
\hline Sodium chloride & $101^{\mathrm{a}}$ & $102^{a b}$ & $72^{\mathrm{a}}$ & $65^{\mathrm{ab}}$ & $60^{\mathrm{bc}}$ & 71 \\
\hline Potassium chloride & $90^{\mathrm{a}}$ & $108^{a}$ & $38^{\mathrm{e}}$ & $52^{\mathrm{bc}}$ & $74^{a}$ & 72 \\
\hline Lysine monohydrochloride & $100^{\mathrm{a}}$ & $102^{a b}$ & $48^{\mathrm{bc}}$ & $48^{\mathrm{c}}$ & $60^{\mathrm{bc}}$ & 67 \\
\hline Lysine monohydrochloride & & & & & & \\
\hline + calcium & $103^{a}$ & $91^{\mathrm{b}}$ & $57^{\mathrm{b}}$ & $70^{\mathrm{a}}$ & $63^{b}$ & 60 \\
\hline Pooled SEM & $5 \cdot 4$ & $4 \cdot 3$ & $4 \cdot 1$ & $3 \cdot 3$ & $2 \cdot 9$ & $2 \cdot 8$ \\
\hline
\end{tabular}

a, b,c, Means in columns with unlike superscript letters were significantly different $(P<0.05)$.

* For details of procedures, see pp. 524-525.

$\dagger$ For details of dietary treatments, see p. 524.

$\mathrm{NaHSO}_{4}, \mathrm{KHSO}_{4}, \mathrm{NaHCO}_{3}$ or $\mathrm{KHCO}_{3}$ weighed 319, 309, 299, 240, 270, 307 and $292 \mathrm{~g}$ respectively. Those rats fed on $\mathrm{NaHSO}_{4}$ weighed less than all other rats; those rats fed on $\mathrm{KHSO}_{4}$ weighed less than rats fed on the basal diet or diets supplemented with $\mathrm{NaCl}, \mathrm{KCl}$ or $\mathrm{NaHCO}_{3}$.

Excess dietary $\mathrm{Cl}$ was efficiently excreted in urine (Table 4). Changes in dietary sources of $\mathrm{Cl}$ had little impact on its excretion. However, in study $\mathrm{A}$ after 16 weeks, rats fed on lysine monohydrochloride with calcium excreted $\mathrm{Cl}$ less efficiently than rats fed on $\mathrm{KCl}$. 
Table 5. Study $A^{*}$. Apparent absorption (\%) of chloride, sodium and potassium by rats fed on various chloride salts $\dagger$

(Values are means of eight observations)

\begin{tabular}{|c|c|c|c|c|c|}
\hline \multirow[b]{2}{*}{ Dietary treatments } & \multirow[b]{2}{*}{$\begin{array}{l}\text { Apparent absorption } \mathrm{Cl} \\
\text { Week } 16\end{array}$} & \multicolumn{2}{|c|}{ Apparent absorption $\mathrm{Na}$} & \multicolumn{2}{|c|}{ Apparent absorption $\mathrm{K}$} \\
\hline & & Week 7 & Week 16 & Week 7 & Week 16 \\
\hline $\begin{array}{l}\text { Basal } \\
\text { Basal supplemented with: }\end{array}$ & $94 \cdot 9^{b}$ & $94 \cdot 9^{\mathrm{be}}$ & $9 \mathrm{I} \cdot 1^{b}$ & $91 \cdot 3^{\circ}$ & $85 \cdot 8^{\mathrm{c}}$ \\
\hline Sodium chloride & $97 \cdot 4^{\mathrm{a}}$ & $97 \cdot 5^{\mathrm{a}}$ & $96 \cdot 8^{\mathrm{a}}$ & $93 \cdot 2^{\mathrm{b}}$ & $91 \cdot 2^{\mathrm{b}}$ \\
\hline Potassium chloride & $97.5^{\mathrm{a}}$ & $93 \cdot 6^{\mathrm{d}}$ & $90 \cdot 9^{\mathrm{b}}$ & $96 \cdot 5^{\mathrm{a}}$ & $95 \cdot 9^{\mathrm{a}}$ \\
\hline Lysine monohydrochloride & $97 \cdot 5^{\mathrm{a}}$ & $96 \cdot 0^{\mathrm{b}}$ & $94 \cdot 8^{\mathrm{a}}$ & $94 \cdot 3^{\mathrm{b}}$ & $91 \cdot 0^{\mathrm{b}}$ \\
\hline $\begin{array}{l}\text { Lysine monohydrochloride } \\
\text { +calcium }\end{array}$ & $96 \cdot 7^{\mathrm{a}}$ & $94 \cdot 7^{\mathrm{cd}}$ & $91.9^{\mathrm{b}}$ & $93 \cdot 3^{\mathrm{h}}$ & $90 \cdot 2^{\mathrm{b}}$ \\
\hline Pooled SEM & $0 \cdot 4$ & 0.4 & 0.8 & 0.6 & 1.0 \\
\hline
\end{tabular}

a, b,c, Means in columns with unlike superscript letters were significantly different $(P<0.05)$.

* For details of procedures, see pp. 524 525 .

$\dagger$ For details of dietary treatments, see p. 524 .

The apparent absorption of $\mathrm{Cl}$ by rats was extremely efficient, ranging from 94.9 to $97.5 \%$ (Table 5). Apparent absorption of $\mathrm{Cl}$ in rats fed on diets supplemented with $\mathrm{Cl}$ was about $2-3 \%$ higher than among rats fed on the basal diet.

Excretion of $\mathrm{Na}$ and $\mathrm{K}$ was somewhat more sensitive to changes in the type of $\mathrm{Cl}$ salts or other anions fed. In study $\mathrm{A}$, rats fed on supplemental $\mathrm{NaCl}$ or lysine monohydrochloride with $\mathrm{Ca}$ excreted $\mathrm{Na}$ in urine more efficiently than rats fed on the basal diet or supplemental $\mathrm{KCl}$ at 7 weeks. Rats fed on supplemental Na or lysine monohydrochloride in study A also absorbed $\mathrm{Na}$ from the gut more efficiently than rats fed on $\mathrm{KCl}$ or lysine monohydrochloride with calcium for 7 or 16 weeks. Apparent absorption of $\mathrm{Na}$ was more efficient among rats fed on $\mathrm{NaCl}$ rather than lysine monohydrochloride at 7 weeks.

The efficiency of urinary excretion of $\mathrm{K}$ was greater among rats fed on $\mathrm{KCl}$ than among other rats after 7 weeks, but the differences were not statistically significant after 16 weeks. Percentage apparent absorption of $\mathrm{K}$ was also consistently greater among rats fed on $\mathrm{KCl}$ than among rats fed on other diets, but rats fed any of the supplemental chloride salts absorbed $\mathrm{K}$ more efficiently than rats fed on the basal diet.

Because $\mathrm{Na}$ and $\mathrm{K}$ excretion appeared to be affected by the anions fed in study $\mathrm{A}, \mathrm{Na}$ and $\mathrm{K}$ excretion and retention in tissues were examined more thoroughly in studies 1 and 2 . In study 1 rats fed on excess $\mathrm{Na}$, regardless of the accompanying anions, excreted $\mathrm{Na}$ more efficiently than rats fed on the basal diet (Table 6). However, the efficiency of urinary $\mathrm{Na}$ excretion was greater when $\mathrm{CO}_{3}$ rather than $\mathrm{HSO}_{4}$ was fed. The findings from study 2 confirmed the observations of study 1 . Efficiency of $\mathrm{Na}$ excretion tended to be greater when $\mathrm{Na}$ rather than $\mathrm{K}$ salts were fed. Despite these variations in the efficiency of Na excretion and apparent absorption, $\mathrm{Na}$ concentrations in kidneys did not change when excess $\mathrm{Na}$ or $\mathrm{K}$ were ingested. The higher concentration of $\mathrm{Na}$ in tibias of rats fed on $\mathrm{Na}_{2} \mathrm{HSO}_{4}$ partly refiects their smaller size in study 2 .

The efficiency of urinary excretion of $\mathrm{K}$ was greatest in study 1 when $\mathrm{NaCO}_{3}$ or $\mathrm{NaHCO}_{3}$ was fed and lowest when $\mathrm{NaHSO}_{4}$ was fed (Table 7). Similarly in study 2, the efficiency of urinary excretion of $\mathrm{K}$ was greatest when $\mathrm{NaHCO}_{3}$ or $\mathrm{KHCO}_{3}$ was fed and lowest when $\mathrm{KHSO}_{4}$ was fed. Despite the large differences in urinary excretion of $\mathrm{K}$, tissue $\mathrm{K}$ concentrations did not vary. 
Table 6. Studies 1 and $2 \|$. Urinary excretion and tissue concentrations of sodium among rats fed on sodium or potassium salts of various inorganic anions

(Values are means of eight observations)

\begin{tabular}{|c|c|c|c|}
\hline Dietary treatments & $\begin{array}{c}\text { Urinary Na:l\| } \\
(\% \text { intake })\end{array}$ & $\begin{array}{c}\text { Tibia Na\|l\| } \\
\text { (mg/g tibia) }\end{array}$ & $\begin{array}{c}\text { Kidney Na } \\
\text { (mg/g kidney) }\end{array}$ \\
\hline \multicolumn{4}{|l|}{ Study 1} \\
\hline Basal & $52 * *$ & $4 \cdot 69$ & 1.53 \\
\hline \multicolumn{4}{|l|}{ Basal supplemented with: } \\
\hline Sodium chloride & 86 & $4 \cdot 71$ & $1 \cdot 52$ \\
\hline Sodium sulphate & $87+\uparrow$ & $4 \cdot 80$ & $1 \cdot 56$ \\
\hline Sodium bisulphate & $77+\dagger$ & $4 \cdot 89$ & $1 \cdot 54$ \\
\hline Sodium carbonate & 95 & 4.87 & 1.57 \\
\hline Sodium bicarbonate & 88 & $4 \cdot 84$ & 1.60 \\
\hline Pooled SEM & $2 \cdot 5$ & 0.06 & 0.02 \\
\hline \multicolumn{4}{|l|}{ Study 2} \\
\hline Basal & $52^{*}$ & $4 \cdot 49$ & $1 \cdot 51$ \\
\hline \multicolumn{4}{|l|}{ Basal supplemented with: } \\
\hline Sodium chloride & $77 \$+$ & $4 \cdot 51 \div$ & $1 \cdot 54$ \\
\hline Potassium chloride & $54^{++}$ & $4 \cdot 46$ & $1 \cdot 54$ \\
\hline Sodium bisulphate & $48+$ & $4 \cdot 72 \ddagger$ & 1.53 \\
\hline Potassium bisulphate & 78 & $4 \cdot 47^{\top}$ & $1 \cdot 49$ \\
\hline Sodium bicarbonate & $76 \pm \ddagger$ & $4 \cdot 45+\$$ & 1.58 \\
\hline Potassium bicarbonate & $44^{++}$ & $4 \cdot 46 \S$ & $1 \cdot 56$ \\
\hline Pooled SEM & $2 \cdot 6$ & 0.06 & 0.03 \\
\hline
\end{tabular}

Values for basal diet were significantly different from those for all other treatments: ${ }^{*} P<0.05,{ }^{* *} P<0.01$.

Values for basal diet supplemented with $\mathrm{Na}_{2} \mathrm{SO}_{4}$ or $\mathrm{NaHSO}_{4}$ were significantly different from those for basal diet supplemented with $\mathrm{Na}_{2} \mathrm{CO}_{3}$ or $\mathrm{NaHCO}_{3}: \dagger+P<0.01$.

Values for high-Na treatments were significantly different from those for high-K treatments: $\ddagger P<0 \cdot 05, \ddagger \ddagger P$ $<0.01$.

Values for $\mathrm{HCO}_{3}$ treatments were significantly different from those for $\mathrm{HSO}_{4}$ treatments: $\S P<0 \cdot 05$.

$\|$ For details of procedures, see pp. 524-525.

- For details of treatments, see p. 524.

\|l $\|$ Significant comparisons by orthogonal contrasts.

\section{DISCUSSION}

Most investigators studying the effects of dietary salt on blood pressure have attributed the effect to Na (Luft \& Weinberger, 1982). The findings from study 1 were consistent with the hypothesis that $\mathrm{Na}$ is a factor in the aetiology of hypertension. The rats fed on excess $\mathrm{Na}$ as $\mathrm{NaCl}, \mathrm{Na}_{2} \mathrm{SO}_{4}, \mathrm{NaHSO}_{4}, \mathrm{Na}_{2} \mathrm{CO}_{3}$ or $\mathrm{NaHCO}_{3}$ had elevated blood pressure after 7 weeks.

However, our previous work (Kaup et al. 1991) and the work of Kotchen et al. (1983) and Whitescarver et al. (1984) demonstrated that rats fed on excess chloride as $\mathrm{NaCl}, \mathrm{KCl}$ or lysine monohydrochloride had elevated blood pressure. Similarly in study 2, we demonstrated that rats fed on $\mathrm{KCl}$ had higher blood pressures than rats fed on the basal diet.

In study 2 we also found that rats fed on excess electrolytes with $\mathrm{HSO}_{4}, \mathrm{Cl}$ or $\mathrm{HCO}_{3}$ had elevated blood pressures. These findings suggest that examining the effect on blood pressure of individual dietary anions or cations may be counterproductive, and that perhaps the total amount of inorganic anions and cations consumed may be more important, at least with this model.

A number of investigators attempting to explain the effects of electrolytes on blood pressure have examined the effect of infusion or ingestion of two or three salts on plasma renin activity. Kotchen et al. (1980) and Kirchner et al. (1978) reported that the infusion of $\mathrm{NaCl}$, lysine monohydrochloride or hydrochloric acid but not sulphuric acid or 
Table 7. Studies 1 and 2\|. Urinary excretion and tissue concentrations of potassium among rats fed on sodium or potassium salts of various inorganic anions $\uparrow$

(Values are means of eight observations)

\begin{tabular}{|c|c|c|c|}
\hline Dietary treatments & $\begin{array}{l}\text { Urinary } \mathrm{K}\|\| \\
\quad(\% \text { intake })\end{array}$ & $\begin{array}{c}\text { Tibia K } \\
\text { (mg/g tibia) }\end{array}$ & $\begin{array}{c}\text { Kidney K } \\
\text { (mg/g kidney) }\end{array}$ \\
\hline \multicolumn{4}{|l|}{ Study 1} \\
\hline Basal & 71 & $1 \cdot 22$ & $2 \cdot 11$ \\
\hline \multicolumn{4}{|l|}{ Basal supplemented with: } \\
\hline Sodium chloride & $67^{*}$ & $1 \cdot 17$ & $2 \cdot 08$ \\
\hline Sodium sulphate & $73+t+t$ & $1 \cdot 16$ & $2 \cdot 20$ \\
\hline Sodium bisulphate & $62+\uparrow$ & $1 \cdot 20$ & $2 \cdot 15$ \\
\hline Sodium carbonate & 86 & $1 \cdot 15$ & $2 \cdot 20$ \\
\hline Sodium bicarbonate & 82 & $1 \cdot 21$ & $2 \cdot 19$ \\
\hline Pooled SEM & $2 \cdot 8$ & 0.03 & 0.07 \\
\hline \multicolumn{4}{|l|}{ Study 2} \\
\hline Basal & 64 & $1 \cdot 25$ & 2.48 \\
\hline \multicolumn{4}{|l|}{ Basal supplemented with: } \\
\hline Sodium chloride & 66 & 1.23 & $2 \cdot 38$ \\
\hline Potassium chloride & 73 & $1 \cdot 18$ & $2 \cdot 45$ \\
\hline Sodium bisulphate & 55 & 1.25 & $2 \cdot 46$ \\
\hline Potassium bisulphate & 35 & $1 \cdot 25$ & $2 \cdot 26$ \\
\hline Sodium bicarbonate & $72 \S \S$ & 1.29 & $2 \cdot 26$ \\
\hline Potassium bicarbonate & $77 \S \S$ & $1 \cdot 28$ & $2 \cdot 32$ \\
\hline Pooled SEM & $2 \cdot 9$ & 0.03 & 0.06 \\
\hline
\end{tabular}

Values for basal diet supplemented with $\mathrm{NaCl}$ were significantly different from those of other high- $\mathrm{Na}$ treatments: ${ }^{*} P<0.05$.

Values for basal diet supplemented with $\mathrm{Na}_{2} \mathrm{SO}_{4}$ or $\mathrm{NaHSO}_{4}$ were significantly different from those for basal diet supplemented with $\mathrm{Na}_{2} \mathrm{CO}_{3}$ or $\mathrm{NaHCO}_{3}: \dagger+P<0.01$.

Values for basal diet supplemented with $\mathrm{Na}_{2} \mathrm{SO}_{4}$ were significantly different from those for basal diet supplemented with $\mathrm{NaHSO}_{4}: \ddagger \ddagger P<0 \cdot 01$.

Values for basal diets supplemented with $\mathrm{NaHCO}_{3}$ or $\mathrm{KHCO}_{3}$ were significantly different from those for basal diet supplemented with $\mathrm{NaHSO}_{4}$ or $\mathrm{KHSO}_{4}: \S \S P<0 \cdot 01$.

II For details of procedures, see pp. 524-525.

For details for dietary treatments, see p. 524.

|| || Significant comparisons by orthogonal contrasts.

$\mathrm{NaHCO}_{3}$, decreased plasma renin activity. Stephens et al. (1978) observed that infusion of sodium lactate, potassium lactate or potassium sulphate depressed renin secretion. Kurtz et al. (1987) reported that ingestion of $\mathrm{NaCl}$ or sodium citrate suppressed plasma renin activity in male subjects. Our findings from study 2 are consistent with the previous findings. Plasma renin activity of rats on $\mathrm{Na}$ or $\mathrm{K}$ salts was lower than that of rats fed on the basal diet. Our findings suggest that $\mathrm{K}$ had greater effects on plasma renin than $\mathrm{Na}$.

The sensitivity of Sprague-Dawley rats to dietary changes in these studies may reflect their tendency to develop nephropathy with age. Among male Sprague-Dawley rats, histological changes are noted in glomerular basement membranes at 3 months and $81 \%$ have chronic progressive nephropathy by 2 years of age (Goldstein et al. 1988). In the present study, a semi-purified diet with generous amounts of protein $(200 \mathrm{~g}$ lactalbumin $/ \mathrm{kg})$ and high amounts of sugar $(500 \mathrm{~g}$ sucrose $/ \mathrm{kg}$ ) was fed from weaning; this could increase the sensitivity of the rats to the electrolyte load.

One means by which renal impairment could ultimately affect blood pressure is through alterations in the size of fluid compartments. However, plasma volumes of rats after 7 weeks of dietary treatments in study 1 did not differ despite differences in blood pressure. Similarly, Whitescarver et al. (1986) found no difference in plasma volume between Dahl salt-sensitive rats fed on high or low levels of $\mathrm{NaCl}$. Perhaps transient changes in fluid 
compartments occurred in our rats before 5 weeks, but compensation occurred. However, Simchon et al. (1989) observed that increased plasma volumes among Dahl salt-sensitive rats fed on additional $\mathrm{NaCl}$ were sustained for at least 4 weeks.

Our observation in study 2 that plasma ANP varied among treatments but not in a consistent pattern suggests that adjustments may have occurred. ANP, which is secreted by atrial myocytes, initially induces hyperfiltration in the kidneys and suppresses renin release (Brenner et al. 1990). This ultimately leads to natriuresis. In all three studies, urinary $\mathrm{Na}$ excretion tended to be more efficient when $\mathrm{NaCl}$ rather than basal diet was fed, but there were no correlations between plasma ANP levels and excretion of $\mathrm{Na}, \mathrm{K}$ or $\mathrm{Cl}$ in study 2 . In future work, plasma volume, renin activity and ANP concentrations need to be monitored before changes in blood pressure are observed.

Another potential way that changes in dietary intake of electrolytes could ultimately affect blood pressure is through tissue electrolyte composition. However, kidney and bone concentrations of $\mathrm{Na}$ and $\mathrm{K}$ were insensitive to the dietary alterations in studies 1 and 2 .

Several groups have observed that tissue $\mathrm{K}$ levels were depleted when metabolic acidosis was induced by feeding ammonium chloride (Lemann et al. 1965; Scandling \& Ornt, 1987; Ching et al. 1989). However, ingestion of $\mathrm{NaCl}$ or $\mathrm{Na}_{2} \mathrm{SO}_{4}$ did not induce excess excretion of acid in these studies (Greger et al. 1991). Moreover, rats fed on $\mathrm{CO}_{3}$ or $\mathrm{HCO}_{3}$ in both studies tended to excrete $\mathrm{K}$ more efficiently than the other rats. The ingestion of these anions was associated with reduced urinary acid excretion.

It was observed that the ingestion of supplemental $\mathrm{Na}$ or $\mathrm{K}$ salts of inorganic anions induced elevated blood pressure in rats not bred or surgically altered to be susceptible to hypertension. Further work is needed to characterize the mechanisms by which alterations in electrolyte intake influence blood pressure in this model and to assess its relevance to human hypertension. The amount of $\mathrm{Na}$ fed in these studies was not extreme. The concentration of $\mathrm{Na}$ (on a dry-weight basis) in the diets supplemented with $\mathrm{Na}$ salts was about $130 \%$ of the $\mathrm{Na}$ concentration in average adult diet composites prepared by the Food and Drug Administration in the Total Diet Studies (Pennington et al. 1984).

This research was supported by the College of Agricultural and Life Sciences, University of Wisconsin-Madison Project 2623 and USDA Competitive Grant 87-CRCR-1-2323.

\section{REFERENCES}

American Institute of Nutrition (1977). Report of the American Institute of Nutrition ad hoc committee on standards for nutrition studies. Journal of Nutrition 107, 1340-1348.

Brenner, B. M., Ballermann, B. J., Gunning, M. E. \& Zeidel, M. L. (1990). Diverse biological actions of atrial natriuretic peptide. Physiology Review 70, 665-699.

Castenmiller, J. J. M., Mensink, R. P., van der Heijden, L., Kouwenhoven, T., Hautvast, J. G. A. J., de Leeuw, P. W. \& Schaafsma, G. (1985). The effect of dietary sodium on urinary calcium and potassium excretion in normotensive men with different calcium intakes. American Journal of Clinical Nutrition 41, 52-60.

Charlton, J. A. \& Armstrong, D. G. (1989). The effect of varying the sodium or potassium intake, or both, on magnesium status in the rat. British Journal of Nutrition 62, 399-406.

Ching, S. V., Fettman, M. J., Hamar, D. W., Nagode, L. A. \& Smith, K. R. (1989). The effect of chronic dietary acidification using ammonium chloride on acid-base and mineral metabolism in the adult cat. Journal of Nutrition 119, 902-915.

Goldstein, R. S., Tarloff, J. B. \& Hook, J. B. (1988). Age-related nephropathy in laboratory rats. FASEB Journal 2, 2241-2251.

Greger, J. L., Kaup, S. M. \& Behling, A. R. (1991). Calcium, magnesium and phosphorus utilization by rats fed sodium and potassium salts of various inorganic anions. Journal of Nutrition 121, 1382-1388

Greger, J. L., Krashoc, C. L. \& Krzykowski, C. E. (1987). Calcium, sodium and chloride interactions in rats. Nutrition Research 7, 401-412.

Greger, J. L. \& Snedeker, S. M. (1980). Effect of dietary protein and phosphorus levels on the utilization of zinc, copper and manganese by adult males. Journal of Nutrition 110, 2243-2253.

Jeffery, P. G. \& Hutchinson, D. (1981). Chemical Methods of Rock Analysis, 3rd ed., pp. 141-142. Oxford: Pergamon Press. 
Kaup, S. M. \& Greger, J. L. (1990). Effect of various chloride salts on the utilization of phosphorus, calcium and magnesium. Journal of Nutritional Biochemistry 1, 542-548.

Kaup, S. M., Greger, J. L., Marcus, M. S. K. \& Lewis, N. M. (1991). Effect of chronic ingestion of various chloride salts on blood pressure, fluid compartments and utilization of chloride. Journal of Nutrition 121, 330-337.

Kirchner, K. A., Kotchen, T. A., Galla, J. H. \& Luke, R. G. (1978). Importance of chloride for acute inhibition of renin by sodium chloride. American Journal of Physiology 235, F444-F450.

Kotchen, T. A., Krzyzaniak, K. E., Anderson, J. E., Ernst, C. B., Galla, J. H. \& Luke, R. G. (1980). Inhibition of renin secretion by $\mathrm{HCl}$ is related to chloride in both dog and rat. American Journal of Physiology 239, F44-F49.

Kotchen, T. A., Luke, R. G., Ott, C. E., Galla, J. H. \& Whitescarver, S. (1983). Effect of chloride on renin and blood pressure responses to sodium chloride. Annals of Internal Medicine 98, 817-822.

Kurtz, T. W., Al-Bander, H. A. \& Morris, R. C. Jr (1987). 'Salt-sensitive' essential hypertension in men. New England Journal of Medicine 317, 1043-1048.

Lemann, J. Jr, Lennon, E. J., Goodman, A. D., Litzow, J. R. \& Relman, A. S. (1965). The net balance of acid in subjects given large loads of acid or alkali. Journal of Clinical Investigation 44, 507-517.

Luft, F. C. \& Weinberger, M. H. (1982). Sodium intake and essential hypertension. Hypertension 4, Suppl. III, III 14 III 19.

Pennington, J. A. T., Wilson, D. B., Newell, R. F., Harland, B. F., Johnsen, R. D. \& Vanderveen, J. E. (1984). Selected minerals in food surveys, 1974 to 1981/1982. Journal of the American Dietetic Association 84, 771-780.

SAS Institute Inc. (1985). SAS/STA $T^{T M}$ Guide for Personal Computers, version 6 ed. Cary, NC: SAS Institute Inc.

Scandling, J. D. \& Ornt, D. B. (1987). Mechanism of potassium depletion during chronic metabolic acidosis in the rat. American Journal of Physiology 252, F122-F130.

Simchon, S., Manger, W. M., Carlin, R. D., Peeters, L. L., Rodriguez, J., Batista, D., Brown, T., Merchant, N. B., Jun, K. M. \& Chien, S. (1989). Salt-induced hypertension in Dahl salt-sensitive rats. Hypertension 13, 612-621.

Stephens, G. A., Davis, J. O., Freeman, R. H. \& Watkins, C. E. (1978). Effect of sodium and potassium salts with anions other than chloride on renin secretion in the dog. American Journal of Physiology 234, F10-F15.

Tarazi, R. C. (1976). Hemodynamic role of extracellular fluid in hypertension. Circulation Research 38, Suppl. II, II $73-$ II 83.

Whitescarver, S. A., Holtzclaw, B. J., Downs, J. H., Ott, C. E., Sowers, J. R. \& Kotchen, T. A. (1986). Effect of dietary chloride on salt-sensitive and renin-dependent hypertension. Hypertension 8, 56-61.

Whitescarver, S. A., Ott, C. E., Jackson, B. A., Guthrie, G. P. Jr \& Kotchen, T. A. (1984). Salt-sensitive hypertension: contribution of chloride. Science 332, 1430-1432.

Whiting, S. J. \& Cole, D. E. C. (1986). Effect of dietary anion composition on acid-induced hypercalciuria in the adult rat. Journal of Nutrition 116, 388-394.

Whiting, S. J. \& Draper, H. H. (1981). Effect of chronic acid load as sulfate or sulfur amino acids on bone metabolism in adult rats. Journal of Nutrition 111, 1721-1726. 